\title{
SEQUENTIAL ANALYSIS OF METALS IN MUNICIPAL DUMPSITE COMPOSTS OF KANO METROPOLIS, NIGERIA
}

\author{
Jimoh, W.L.O. and Sabo, Y. \\ Department of Pure and Industrial Chemistry, Bayero University,P.M.B. 3011, Kano - Nigeria. \\ Saboyusuf18@yahoo.com
}

\begin{abstract}
The heavy metals contents (Pb, Cu, Fe, Cr, Cd, Zn, Mn and Ni) in Municipal dumpsite compost were determined by the sequential extraction method. Chemical parameters such as pH, conductivity, and organic carbon contents of the samples were also determined. Analysis of the extracts was carried out by atomic absorption spectrophotometer machine (Buck Scientific VPG 210). Results of these analyses showed that $\mathrm{Pb}, \mathrm{Ni}, \mathrm{Cr}, \mathrm{Mn}$ and Fe were largely associated with residual fraction (53.06\%, 56.26\%, 58.15\%, 59.14\% and 64.10\% respectively). Cu, Cd and Zn were largely associated with non-residual fractions (71.42\%, $54.44 \%$, and $54.15 \%$ respectively). Calculated mobility and bioavailability factors of $\mathrm{Cd}$, $\mathrm{Zn}$ and $\mathrm{Cu}$ were also high (54.54\%, 54.16\%, 53.06\% and 0.54, 0.54, 0.53 respectively), moderate for Pb, Cr, Ni, Mn, and Fe (46.94\%, 41.86\%, 43.74\%, $40.85 \%, 35.90 \%$ and $0.46,0.41,0.43,0.40,0.35$ respectively). Mean percentage recoveries were ranged from $79.75 \%-100 \%$.
\end{abstract}

Keywords: Municipal dumpsite, compost, sequential extraction, mobility factor, bioavailability factor.

\section{INTRODUCTION}

Metals are present in municipal dumpsites composts in different chemical forms, which influence their reactivity and hence their mobility and bioavailability. Apart from the sites of mineral extraction and application of sludge, uncontrolled Municipal dumpsites are increasingly seen as a source of soil pollution. These dumpsites are places where various products are stored (Ostman et al., 2006). Wastes degradation leads to the pollution of soil by many pollutants through leachate seepage. The composts around the dumpsites are therefore subjected to different types of pollution including those caused by heavy elements. Metals such as cadmium, mercury and arsenic are the most hazardous (Park and Shin, 2006). The risks associated with the presence of heavy metals are varied and depend on their chemical forms (metal, oxide, salt and organometallic) (Kashem et al., 2007). The impact of these metals in composts is their possible transfer into water or plants which is defined in terms of bioavailability. $\mathrm{Cd}$ and $\mathrm{Pb}$ are considered as the most important environmental pollutants in agricultural soils because of the potential harmful effects they may have on food quality and health of soil (Onweremadu and Duruigbo, 2007).

Metal in soils can be divided into two fractions (Rachou and Sauve, 2008): (1) Inert fraction, assumed as the non-toxic fraction, and (ii) the labile fraction, assumed to be potentially toxic. To assess the availability of heavy metals, only the soil labile fraction is taken into account because it is often called by extension, the bioavailability fraction (Gray et al., 2004). However, the bio available fraction can differ from one metal to another and from one receptor to another. The availability of metals for plants and micro-organisms in soil depends on the composition of the different compartments of soil such as carbonates, (oxy) metal hydroxides, organic matter and silica.

The sequential extraction was used to highlight the relationship between the compartments of compost and metals, and to assess the mobility, bioavailability and the potential threat of heavy metals to the environment.

\section{MATERIALS AND METHODS}

\section{Study Area and Sample Collection}

The composts samples were collected from twelve different - sampling points $(0-15 \mathrm{~cm}$ depth) in Kano metropolis into polyethylene bags with plastic spoon. Samples were immediately taken to the laboratory, extraneous materials were removed; the samples were air-dried, crushed and grinded to a fine powder in a mortar passed through a $0.20 \mathrm{~mm}$ sieve. The compost samples were homogenized and stored in clean polyethylene bags in a dessicator till the analysis. Precautionary measures were taken to avoid contamination during sampling, grinding, sieving and storage (Tokalioglu et al., 2003).

Reagents: Analytical reagent grade chemicals and de ionized water were used for preparing all solutions. Stock solutions containing $1000 \mathrm{mgL}^{-1}$ of the analytes were prepared from nitrate salts of $\mathrm{Pb}, \mathrm{Cu}, \mathrm{Fe}, \mathrm{Cr}, \mathrm{Cd}$, $\mathrm{Zn}, \mathrm{Mn}$ and $\mathrm{Ni}$ in $1 \%$ of $\mathrm{HNO}_{3}$ into calibrated flasks. Working standard solutions were prepared by appropriate dilutions of the stock solutions. Blank determinations were run by using the same reagents in equal quantities as described in the analysis procedure throughout the experiments. Total Metal Analysis: To check the accuracy of the sequential extraction procedures used in the analysis of municipal dumpsite compost samples, the recovery values (\%) were investigated using total metal analysis. 
Exactly, $0.25 \mathrm{~g}$ of the samples was weighed and digested with $6 \mathrm{ml}$ of an acid mixture $\left(\mathrm{HNO}_{3}+\right.$ $\mathrm{HF}+\mathrm{H}_{2} \mathrm{O}_{2}$ ) at ratio of $3: 2: 1$. All the analyses Recovery

$$
\sum_{n}=
$$

sequential extraction procedure

Single digestion with strong acid 7 x 100, ranged from $79.75-100 \%$

Heavy Metal Fractions: In this study, four different extraction procedures were used according to the modified Tessier's method (Blanchard, 2000), to establish the distribution of metal in the compost. The extraction was carried out at room temperature. After each extraction, the mixture was centrifuged (15min, $3000 \mathrm{rpm}$ ) and the supernatant was filtered through no. 41 whatman filter paper.

Water soluble Fractions: Each sample was extracted with $50 \mathrm{~cm}^{3}$ of deionized water. The mixture was shaken for $5 \mathrm{~h}$ at $23^{\circ} \mathrm{C}$ and left to stand overnight.

Reducible Fractions: Metals bound to iron and manganese oxide were extracted by adding $50 \mathrm{~cm}^{3}$ of $0.1 \mathrm{M}$ Hydroxylammonium chloride (adjusted to $\mathrm{pH} 2$ with $2 \mathrm{molL}^{-1}$ nitric acid) onto the residue from the water soluble fraction.

Oxidizable Fractions: Exactly $50 \mathrm{~cm}^{3}$ of $1.0 \mathrm{M}$ ammonium acetate solution (adjusted to $\mathrm{pH} 2$ with $2 \mathrm{molL}^{-1}$ nitric acid) was added on to the residue from the reducible fraction.

Residual Fractions: The residue from oxidizable fractions after drying in the dessicator for 7days, $0.25 \mathrm{~g}$ was weighed and digested in a platinum crucible with $3 \mathrm{~cm}^{3} \mathrm{HNO}_{3}, 2 \mathrm{~cm}^{3} \mathrm{HF}$ and $1 \mathrm{~cm}^{3} \mathrm{H}_{2} \mathrm{O}_{2}$ on a hot plate. The mixture was evaporated to the dry ness, $40 \mathrm{~cm}^{3}$ of $0.25 \mathrm{M}$ of $\mathrm{HNO}_{3}$ was added. The resulting solution was heated for about 10minutes, and then filtered into $60 \mathrm{ml}$ plastic bottles. Finally, the extracts collected were analyzed using AAS (Bulk scientific VPG 210) to determine the concentrations of $\mathrm{Pb}, \mathrm{Cu}, \mathrm{Fe}, \mathrm{Cr}, \mathrm{Cd}, \mathrm{Zn}$, and $\mathrm{Ni}$ metals in each of the fractions.

\section{Mobility Factor}

The mobility of metals in compost samples may be assessed on the basis of absolute and relative content of fractions weakly bound to components. The relative index of metal mobility was calculated as a "mobility factor." (MF; Kabala and Singh, 2001; Narwal et al., 1999; Salbu et al., 1998) on the basis of the following equation:

Where,

$$
\mathrm{MF}=\frac{\left(F_{1+F_{2}+F_{3}}\right)}{\left(F_{1+F_{2}+F_{3}+F_{4}}\right)} \times 100
$$$$
F_{1}=\text { water soluble fraction }
$$$$
\mathrm{F}_{2}=\text { reducible fraction }
$$$$
\mathrm{F}_{3}=\text { Oxidizable fraction }
$$$$
\mathrm{F}_{4}=\text { Residual fraction }
$$

\section{Bioavailability Factor}

The bioavailability factor is expressed as the ratio of the available concentration of a metal in compost to its total concentration. It shows the potential of a particular metal from the soil matrix to enter the soil solution from which it can be absorbed by plants.

were run in triplicate analysis and recoveries of the eight metals were calculated by using the formula below (Tokalioglu et al., 2003).
J

$\mathrm{BF}$

Available concentraion of a metal in compost Total concentration

Where, available concentration of a metal in compost is the concentration in non - residual fractions.

Total concentration is the concentration in residual and non - residual fractions.

\section{RESULTS AND DISCUSSION}

The mean percentage recoveries of metals are presented in Table 1 . The mean percentage recoveries of metals ranged from $79.75 \%$ $100 \%$.

The results of total metal contents of compost samples are presented in Fiqure.1. The total concentrations of $\mathrm{Zn}$ ranged from 52.18 to $547.82 \mathrm{mg} / \mathrm{kg}$; while $\mathrm{Cu}$ concentrations varied from 34.50 to $262.06 \mathrm{mg} / \mathrm{kg}$ and $\mathrm{Cr}$ level was from 30.76 to $107.68 \mathrm{mg} / \mathrm{kg}$. The Fe level ranged from 18.18 to $109.08 \mathrm{mg} / \mathrm{kg}$ and the concentrations of $\mathrm{Ni}$ was varied from 9.52 to $76.19 \mathrm{mg} / \mathrm{kg}$. The level of $\mathrm{Mn}$ ranged from 12.40 to $73.45 \mathrm{mg} / \mathrm{kg}$, while a concentrations of $\mathrm{Pb}$ and $\mathrm{Cd}$ was ranged from 13.80 to $62.07 \mathrm{mg} / \mathrm{kg}$ and 2.5 to $7.5 \mathrm{mg} / \mathrm{kg}$ respectively. All the compost samples showed highest $\mathrm{Zn}$ concentration followed by $\mathrm{Cu}$ concentrations. The $\mathrm{Cd}$ concentrations were found to be the least as compared to other metals in all the compost samples. The predominance of $\mathrm{Zn}$ in the composts may be attributed to the stabilization of $\mathrm{Zn}$ oxides in the composts, as it was reported that $\mathrm{Zn}$ oxides in soils have high stability constant ( $\mathrm{Ma}$ and Rao, 1997). While in the case of Cd may be due to the weak adsorption nature of $\mathrm{Cd}$ in the soils (Mido and Satake, 2003).

Irrespective of sampling points, the distribution of metals in Municipal dumpsites composts samples generally followed the order below for the various metal studied.

$\mathrm{Pb}$ : residual $>$ oxidizable $>$ reducible $>$ water soluble $\mathrm{Cu}$ : oxidizable $>$ residual $>$ reducible $>$ water soluble Fe: residual $>$ oxidizable $>$ reducible $>$ water soluble Cr: residual $>$ oxidizable $>$ reducible $>$ water soluble $C d$ : residual $>$ reducible $>$ oxidizable $>$ water soluble $\mathrm{Zn}$ : residual $>$ reducible $>$ oxidizable $>$ water soluble $\mathrm{Mn}$ : residual $>$ reducible $>$ oxidizable $>$ water soluble $\mathrm{Ni}$ : residual $>$ oxidizable $>$ reducible $>$ water soluble

The difference in distribution patterns can be inclined towards possible mobilization of the metals. Lead was predominantly in the residual fraction (Figure 1 ). The amount of $\mathrm{Pb}$ in the residual fraction is $53.06 \%$. The highest $\mathrm{Pb}$ content found in the residual fraction in this work is in agreement with the finding of Osakwe and Egharevba (2008) and Asagba et al., (2007). Amongst the nonresidual fractions oxidizable and reducible were found to be the highest (Figure 1). 
Some researchers have also found $\mathrm{Pb}$ to be highly associated with oxidizable form (Tokalioglu et al., 2003). The good percentage of $\mathrm{Pb}$ in the reducible form may be due to ability of $\mathrm{Fe} / \mathrm{Mn}$ oxides to scavenge metals from the soil solution that would normally not precipitate (Asagba et al., 2007). However, water soluble fractions of $\mathrm{Pb}$ were found in a very small percentage. This suggested that $\mathrm{Pb}$ in these composts may not be bio available because water soluble fractions consist of metals species found in the soil solution. The highest percentage of $\mathrm{Cu}$ was found in oxidizable fraction amongst the non residual portion $(46.95 \%)$. The major association of $\mathrm{Cu}$ with oxidizable fraction in these composts may be attributed to the high formation constant of organicCu complexes (Stumm and Morgan, 1981). This result is consistent with that of Harrison (1981) who found significant amount of $\mathrm{Cu}$ associated with oxidizable fractions. The second highest concentration of $\mathrm{Cu}$ was associated with residual fraction $28.58 \%$, followed by reducible fraction $23.47 \%$ and the least percentage of $\mathrm{Cu}$ was associated in water soluble $1.02 \%$. The poor presence of $\mathrm{Cu}$ in water soluble fraction may be as a result of high stability of $\mathrm{Cu}$ in the $\mathrm{Cu}$ organic complexes. Under oxidizing conditions copper can be leached into the environment (Venkateswaran et al., 2007). Because of this copper may be considered as mobile element and bioavailable for plant uptake. Iron, manganese and chromium were predominantly in the residual fractions (Figure. 1).

The amount of $\mathrm{Fe}, \mathrm{Mn}$ and $\mathrm{Cr}$ in the residual fractions are $(64.10 \%),(59.14 \%)$ and $(58.15 \%)$. The highest percentages of $\mathrm{Fe}, \mathrm{Mn}$ and $\mathrm{Cr}$ in this study are in agreement with the finding of Tokalioglu (2003). Because of this, Fe, $\mathrm{Mn}$ and $\mathrm{Cr}$ can be considered as partially mobile and bioavailable for plant uptake, due to the greater percentages of these elements in the residual fraction (aqua regia). This implies that, these metals are strongly bound to minerals and resistant components, and do not represent environmental risk (Petit and Rucanido, 1999). Cadmium is distributed more in residual fraction, with around (45.45\%) (Figure. 1). The second most concentrated fraction was reducible with about $36.37 \%$, followed by oxidizable $(18.18 \%)$. The low percentage of $\mathrm{Cd}$ in the organic fraction is consistent with the low adsorption constant of Cd on organic matter (Baron et al., 1990; Chlopecka et al., 1996) and the fact that Cd does not to form stable organic complexes (Keefer et al., 1984). Cd was found to be the most mobile element because $54.55 \%$ of its total concentrations were in second and third fractions. This high amount of $\mathrm{Cd}$ associated with the non-residual phases, shows that it may be easily transferred into the food chain through uptake by plants growing in the soils. Zinc was predominantly in the residual fraction (Figure. 1). The amount of $\mathrm{Zn}$ in the residual fraction was (45.85\%). The reducible fraction among the non-residual fractions contained the highest concentration of $\mathrm{Zn}$ metal, followed by the oxidizable fraction. The highest amount of $\mathrm{Zn}$ in the reducible fraction could be attributed to the high stability of $\mathrm{Zn}$ oxides; ( $\mathrm{Ma}$ and Rao, 1997). Several other researchers such as Ramos et al., (1994) and Xian, (1989) have also found Zn associated with the reducible fraction. With the high percentages of $\mathrm{Zn}$ in non-residual portion (54.15\%), $\mathrm{Zn}$ metal may be considered as mobile and thus bioavailable for plant uptake. The majority of the $\mathrm{Ni}$ concentrations were in residual fraction (56.25\%). The oxidizable was the second most concentrated fraction followed by reducible fraction. The reducible fraction was also important for non residual fractions in the composts. This may be due to the ability of $\mathrm{Fe}^{2+}$ and $\mathrm{Fe}^{3+}$ species to scavenge metals from soil solution that would normally not precipitate (Asagba et al., 2007). The appreciable percentage of $\mathrm{Ni}$ in the nonresidual fractions of the composts suggested the potential mobility and bioavailability of $\mathrm{Ni}$ into plant. The results of mobility factor of the studied metals are presented in Table 2.

The MF gave values less than $50 \%$ for $\mathrm{Pb}$, $\mathrm{Fe}, \mathrm{Cr}, \mathrm{Mn}$ and $\mathrm{Ni}$, which is a symptom of moderate stability of the above metals in the compost samples. This could be linked to the high organic matter content in the compost which can lead to the formation of insoluble complex compounds which may be limiting the mobility of heavy metals. The $\mathrm{MF}_{\mathrm{cu}}$ is $53.06 \%$, the index for $\mathrm{Zn}$ is $54.16 \%$ and for $\mathrm{Cd}$ is $54.54 \%$. The high MF values have been interpreted as symptoms of relatively high liability and biological availability of heavy metals in soils (Kabala and Singh, 2001; Narwal et al., 1999). Many soil factors such as $\mathrm{pH}$, organic matter content, amounts and forms of oxides and carbonates, charge characteristics, as well as mineral composition influence the bioavailability and transport of heavy metals in the soil and within the agroecosystem (Fageria et al, 2002).

The BF values were found to be moderate; this could be linked to the high organic matter content, which may lead to the formation of insoluble complex compounds limiting the bioavailability of heavy metals. These findings are in agreement with Sauve et al (1998), that heavy metals are capable of forming insoluble complex compound with soil organic matter.

The results showed $\mathrm{BF}$ of $\mathrm{Cd}(0.54), \mathrm{Zn}$ (0.54), Cu (0.53), Pb (0.46), Ni (0.43, Cr (0.41), Mn (0.40) and $\mathrm{Fe}(0.35)$. The sequence of $\mathrm{BF}$ was; $\mathrm{Cd}=$ $\mathrm{Zn}>\mathrm{Cu}>\mathrm{Pb}>\mathrm{Ni}>\mathrm{Cr}>\mathrm{Mn}>\mathrm{Fe}$. Water soluble and exchangeable fractions are considered to be bioavailable, oxide, carbonate and organic matter bound fraction may be potentially bioavailable, to either plants or microorganisms (He et al., 1995). Thus, for the compost samples studied, the residual fraction seems to contain more heavy metals than the bioavailable fraction. Besides, the high BF for Cd, Zn and $\mathrm{Cu}$ suggests that the bioavailable fraction contains more of $\mathrm{Cd}, \mathrm{Zn}$ and $\mathrm{Cu}$ than the residual fraction. 
Table 1: Mean percentage recoveries obtained from the original sample.

\begin{tabular}{ll}
\hline Metals & Mean percentage recoveries (\%) \\
\hline $\mathrm{Cu}$ & 91.42 \\
$\mathrm{~Pb}$ & 79.75 \\
$\mathrm{Fe}$ & 92.17 \\
$\mathrm{Cr}$ & 92.33 \\
$\mathrm{Cd}$ & 100.00 \\
$\mathrm{Zn}$ & 89.25 \\
$\mathrm{Mn}$ & 84.59 \\
$\mathrm{Ni}$ & 84.75 \\
\end{tabular}

*Values are mean of triplicate analyses

Table 2: Mobility and Bioavailability Factors of Heavy Metals in dumpsite composts samples

\begin{tabular}{lll}
\hline Heavy Metal & Mobility Factor (\%) & Bioavailability Factor \\
Lead (Pb) & 46.94 & 0.46 \\
Copper (Cu) & 53.06 & 0.53 \\
Iron (Fe) & 35.90 & 0.35 \\
Chromium (Cr) & 41.86 & 0.41 \\
Cadmium (Cd) & 54.54 & 0.54 \\
Zinc (Zn) & 54.16 & 0.54 \\
Manganese (Mn) & 40.85 & 0.40 \\
Nickel (Ni) & 43.74 & 0.43 \\
\hline
\end{tabular}

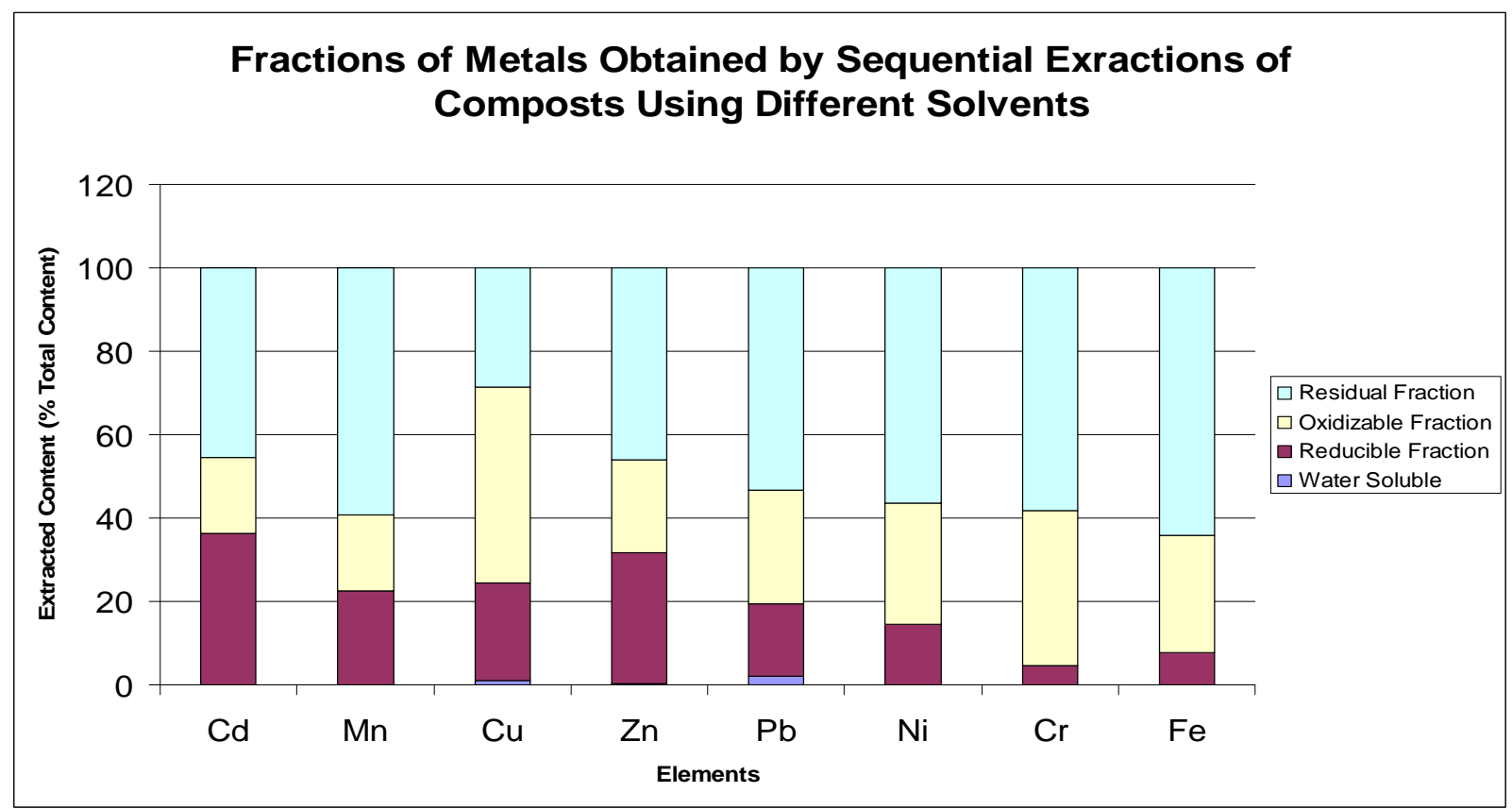

Fig 1: Fractions of Metals Obtained by Sequential Extractions of Composts using different solvents

\section{CONCLUSION}

The increasing amount of total metals $(\mathrm{Pb}, \mathrm{Cu}, \mathrm{Fe}, \mathrm{Cr}$, $\mathrm{Cd}, \mathrm{Zn}, \mathrm{Mn}$ and $\mathrm{Ni}$ ) contents in the compost could be due to human activities. The main source is by the disposal of solid wastes. The residual fraction was the most abundant pool for all metals in the compost examined. However, in most of the composts, a significant percentage of total metals was associated with non residual fractions, which could be possible absorbed by plants. Significant amount of $\mathrm{Cd}, \mathrm{Zn}$ and $\mathrm{Cu}$ were associated with the non-residual fractions in the composts, which indicated that these metals were potentially bioavailable. These may pose a real threat as $\mathrm{Cd}, \mathrm{Zn}$ and $\mathrm{Cu}$ are transferred into the food chain from compost contaminated by these metals.

\section{Recommendations}

In Nigeria, there are little or no information available on the levels of heavy metals in municipal dumpsite composts. In contrast, extensive works have been directed to the characterization and prediction of mobility and bioavailability of heavy metals in municipal dumpsite composts in Europe and U.S.A, since composts generated in Nigeria may be considerably different from those of Europe and U.S.A, it is therefore necessary for Nigerian researchers to pay more attention to this field. Specifically more effort should be in the following directions. 
i.Interactions between organic components and heavy metals.

ii. Development of specific guidelines and standards for application of composts in agricultural lands.

iii. Phase association of heavy metals in composts.

iv. Correlation between extractability and bioavailability.

\section{REFERENCES}

Asagba, E.U., Okeimem, F.E. and Osokpor, J. (2007): Screening and Speciation of Heavy Metal Contaminated Soil from an Automobile Spare-part Market. Chemical Speciation and Bioavailability, 19 (1), 9-15

Baron, J., Legret, M., and Astruc M. (1990): Study of Interactions between Heavy Metals and Sewage Sludge. Determination of Stability Constants and Complexation Capacities of Complexes Formed with $\mathrm{Cu}$ and Cd. Environ. Tehcnol., 11: 151 - 162.

Benitez L.N., Dubois, J.P. (1999). Int. J. Environ. Anal. Hem. $75-261$.

Blanchard, C. (2000): Characterization of the Potential Mobilization of Inorganic Pollutants in Soils Polluted. PhD Dissertation, National Institute of Applied Science of Lyon.

Chlopecka, A., Bacon, J.R., Wilson, M.J. and Kay, J. (1996): Forms of Cadmium, Lead and Zinc in Soils from Southwest Poland. J. Environ. Qual., 25: 69 79.

Davidson, C.M., Thomas, R.P., Mcvey S.E., Perata K., Little Jon D. and Ure A.M. (1994): Anal. Chem. Acta $277-291$

Fageria, N.K., Baligar, V.C., Clark, R.B. (2002): Micronutrients in Crop Production. Adv. Agron. 77: $185-268$.

Gray, C.W., Mclaren, R.G., Gunther, D., Sinaj, S. (2004): An Assessment of Cadmium Availability in Cadmium Contaminated Soils using Kinetic Isotope Exchange. Soil Sci. Soc. Am. J. 68, 1210-1217.

Harrison, R.M. (1981): Chemical Association of Pb, Cd, $\mathrm{Cu}$, and $\mathrm{Zn}$ in Street Dust and Roadsite Soils. Environ. Sco. Technol, 15, $1378-1383$.

Kabala, C., and Singh, B.R (2001): Fractionation and Mobility of Copper, Lead and Zinc in Soil. Profiles in the Vicinity of a Copper Smelter. J. Environ. Qual., 30: 485 - 492

Kashem, M.A., Singh, B.R., Kondo, T., Imamul Huq, S.M. Kawai, S. (2007): Comparison of Extractability of Cd, $\mathrm{Cu}, \mathrm{Pb}$, and $\mathrm{Zn}$ with Sequential Extraction in Contaminated and Non-contaminated Soils. Int. J. Environ. Sci. Tech. 4 (2), 169 - 176.

Keefer, R.F., Codling E.E., and Singh R.N. (1984): Fractionation of Metal-organic Components Extracted from Sludge - amended Soil. Soil Sci. Soc. Am. J., 48: 1054 - 1059.

Ma, L.Q., Rao, G.N. (1997): Chemical Fractionation of Cadmium, Copper, Nickel and Zinc in Contaminated Soils. J. Environ. Qual. 26: 259-264.

Mido, Y. and Satake, M. (2003): Chemicals in the Environment. In Sethi M.S. and Igbal, S.A (eds). Toxic Metals. Discovery publishing House, New Delhi, 45-68.

Narwal, R.P., Singh, B.R., and Salbu, B. (1999): Associations of Cadmium, Zinc, Copper and Nickel
Hopefully, information obtained from studies of these topics will provide a sound basis for both federal and state governments to establish guidelines on municipal dumpsite composts production and application, and for the general public to make objective judgment on composting as a sustainable solution to municipal waste management.

with Components in Naturally Heavy Metal-Rich Soils Studied by Parallel and Sequential Extractions. commun. Soil Sci. Plant Anal. 30: 1209 - 1230.

Onweremadu, E.U.,and Duruigbo, C.I. (2007): Assessment of $\mathrm{Cd}$ Concentrations of Crude Oil Pollution Arable Soils. Int. J. Environ. Sci. Tech. 4 (3), 409-412.

Osakwe, S.A. and Egharevba, E. (2008): Sequential Fractionation of $\mathrm{Cd}, \mathrm{Cu}, \mathrm{Pb}$, and $\mathrm{Cr}$ in Soils Around Municipal Solid Waste Dumps in Agbor, Nigeria Journal of Chemical Society of Nigeria, 33 (2), 139147.

Ostman, M., Wahilberg, O., Agren, S., Martensson, A. (2006): Metal and Organic Matter Contents in a Combined Household and Industrial Landfill. Waste Management, 26, 29-40. Doi:10.1016/j.wasman.2005.01.012

Park, J.H., and Shin, W.S. (2006): Immobilization of Pb Contamined Soil using Modified Clay. Water Practice and Technology, 1 (2), 1-10. Doi: 10.2116/wpt.2006.0035.

Petit, M. and Rucanido, M.T. (1999). Anal. Chem. Acta. $401,283-291$.

Rachou, J., Sauve, S. (2008): Evaluation of Affinity Constants of $\mathrm{Cu}, \mathrm{Cd}$, and $\mathrm{H}$ for Active Soil Surfaces for a Solid Phase-controlled Soil Ligand Model. Environ. Chem, 5, 150-160. Doi:10.1071/EN07093.

Ramos, L., Hermandez L.M., and Gonzales, M.J. (1994): Sequential Fractionation of Copper, Lead, Cadmium and Zinc in Soils from Donana National Park. J. Environ. Qual., 23: 50 - 57.

Salbu, B., Krekling T., and Oughton, D.H. (1998): Characterization of Radioactive Particles in the Environment. Analyst, 123: 843-849.

Sauve, S., Mc Bridge, M.B. and Hendershot, W.H. (1998): Soil Solution Speciation of $\mathrm{Pb}$ (II): Effects of Inorganic Matter and $\mathrm{pH}$, Soil Science Society, 40, 11-22.

Stumm, W. and Morgan, J.J. (1981): Aquatic Chemistry: An Introduction Emphasizing Chemical Equilibrium in Natural Water, $2^{\text {nd }}$ edition. John Wiley and Sons New York.

Tokalioglu, S., Senol, K. and Gokhan, B. (2003): Application of Three Stages Sequential Extraction Procedure for the Determination of Extractable Metal Content in Highway Soils. Turk. J. Chem. 27, 333346.

Venkateswaran, P., Vellaichamy, S., and Palanivelu, K. (2007): Speciation of Heavy Metals in Electroplating Industry Sludge and Waste Water Residue using Inductively Coupled Plasma. Int. J. Environ. Sci. Tech, 4 (4), $497-504$.

Xian, X. (1989): Effect of Chemcial Forms of Cadmium, Zinc and Lead in Polluted Soils on their Uptake by Cabbage plants. Plant soil, 113:257-264 